\title{
Preserving the Architectural Heritage of al-Andalus. From Restoration to Virtual Reconstruction
}

\section{ANTONIO ALMAGRO}

ABSTRACT The legacy of Arab-Muslim architecture in Spain is one of the most valuable parts of the wealthy Spanish heritage. The application of new concepts and practices to the conservation of this architecture has led to numerous examples of restoration which respect historical values, while using the most modern techniques and principles at the same time. Nowadays, virtual reconstruction of buildings that have been destroyed or severely changed, carried out using computer graphics, enables the analysis of such important aspects as visual perception, character given to space by colour and material textures, light effects, etc. Using these means it is also possible to present and study different alternatives or hypotheses without having to make physical alterations to the original elements. These new instruments, with their capacity to transmit knowledge and research results, also offer new ways of understanding the spreading of heritage. Several case studies of the use of these tools applied to al-Andalus architecture are presented.

Keywords: al-Andalus; Mosques; Medina Azahara; Granada; Sevilla; Almohads; Nasrids

\section{Introduction}

The cultural legacy from the Arab-Muslim civilisation in the Iberian Peninsula is one of the most important of Spain's rich Historical Heritage. This legacy has always been really appreciated from the very beginning of its existence, and over the centuries there have been important activities to ensure the conservation and assessment of the legacy. We must remember the constant conservation of the Nasrid Palaces of the Alhambra ${ }^{1}$ or the Alcazar of Seville, ${ }^{2}$ or the mosque of Cordoba, ${ }^{3}$ to mention just the most outstanding cases. However, many of the buildings constructed between the eighth and fifteenth centuries underwent considerable damage and alterations, even during the time of the Muslim occupation of the Iberian Peninsula. Conservation work on al-Andalus architectural

Correspondence: Antonio Almagro, Escuela de Estudios Árabes, CSIC, Cuesta del Chapiz 22, E-18010 Granada, Spain. E-mail: aalmagro@cica.es

\footnotetext{
${ }^{1}$ Alvarez Lopera; Vilchez; also the section "Crónica" in the journal Cuadernos de la Alhambra, published since 1965.

${ }^{2}$ Marin; Chávez; the most recent excavation and restoration works can be followed through the journal Apuntes del Alcázar de Sevilla.

${ }^{3}$ Nieto Cumplido.
} 
heritage took on special significance as from the first decades of the twentieth century, and the amount of restoration which took place in monuments such as the Alhambra is proof of the variety of ways and theories about conservation put into practice over the last one hundred and fifty years.

At present, and owing to the growing awareness of society towards all cultural expression, and particularly towards those items which form part of the architectural and historical heritage, and depending on the new concepts and methods applied to its conservation, there are numerous examples of restoration carried out with regard to the historical values and the most up-to-date techniques and principles.

Since more than fifteen years ago a research group in the School of Arabic Studies of the CSIC (Consejo Superior de Investigaciones Científicas) has been carrying out studies on Islamic Architecture, dealing with the knowledge about this heritage as a base for its conservation, while at the same time using the restoration work and the possibilities it offers as a source of information to extend this knowledge. In this sense, the graphic documentation work, and particularly the elaboration of plans and detailed drawings constitute a considerable part of their activity. ${ }^{4}$ In the search to assess this heritage, new technologies are applied, not only to improve our knowledge but also to communicate to society our progress in this area. On the other hand, this new technology offers the possibility of overcoming the limitations imposed on the restoration works by considering the monument as a historical document, which hinders the carrying out of actions based on mere hypotheses and which may lead to confusion in their interpretation.

\section{Some recent examples of restoration}

We would like to put forward some significant examples of the latest activity carried out in Spain, including some cases of restoration of archaeological remains, of architectural monuments and historic gardens. These examples show the different problems which have to be faced, including some works directed by the author, and others carried out by professional people in the restoration world.

The archaeological site of Madinat al-Zahrā' is one of the most outstanding ones in Spain (Figure 1), both for being the object of pioneering medieval archaeological investigation and for its historical and artistic importance. ${ }^{5}$ However, there are very specific problems of conservation of the remains of what was the palatine city of the Ummayad caliphs of al-Andalus, situated just a few kilometres from Cordoba, which had a very ephemeral existence, since it lasted only seventy years. Maybe the most significant problem is due to the fact that for many centuries it had been plundered of its materials as though it were a quarry. This gave place to the almost complete disappearance of many of its architectural structures, although not so its decoration, since this was of no use as material for construction and was abandoned in situ, and a high percentage of the decorative elements appeared in the excavations, although they were broken into fragments. The finely carved limestone panels are to be found in thousands of pieces, like an enormous jigsaw puzzle which, when mounted together, provides us with splendid pieces of Ummayad caliphal art, as well as vital information about the buildings it adhered to.

\footnotetext{
${ }^{4}$ As an example of new survey works see Almagro (1996).

${ }^{5}$ Velázquez; Hernández; Vallejo; Almagro (2001).
} 


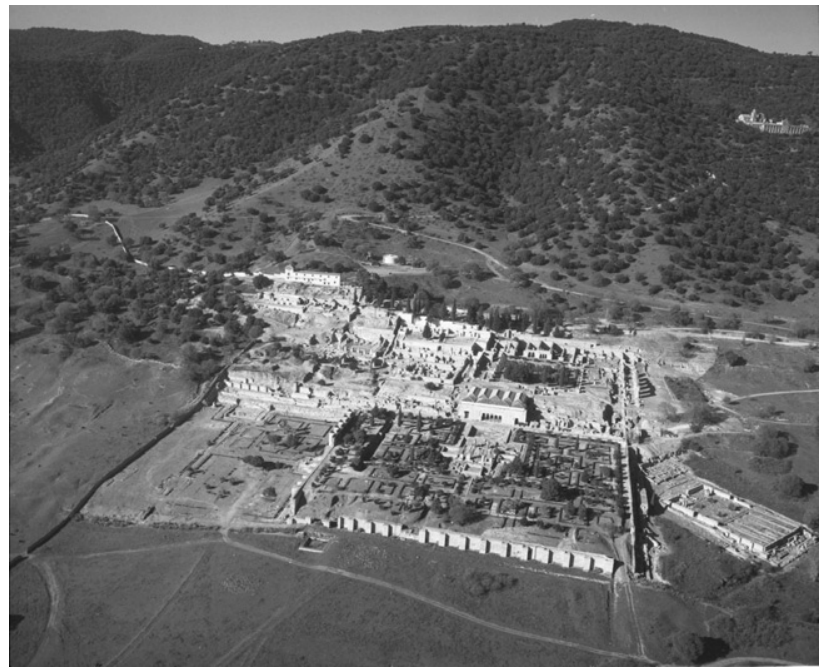

FIgURE 1. General view of the archaeological site of Madinat al-Zahrā'.

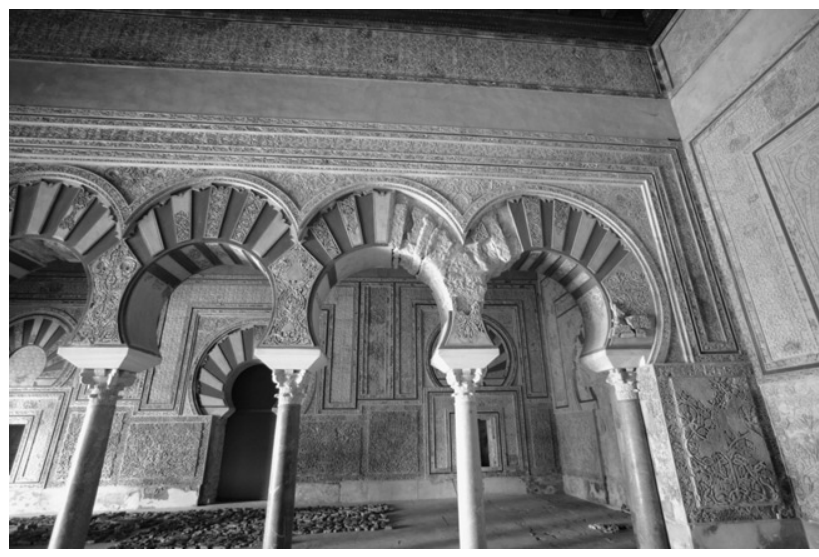

FIgURE 2. Interior of the reception hall of 'Abd al-Raḥmān III in Madinat al-Zahrā'.

The dilemma which confronts us is what to do with these pieces; whether they should be destined as purely archaeological material to be stored or exhibited in a museum, which would require spaces similar to their original location, or whether to replace them as they were originally, which would mean reconstructing the missing architectural structures. I think that this latter solution has rightly been adopted in those places in which the decoration was sufficient to permit the characteristics and shapes of the original buildings to be deduced. This has been the case of the outstanding reception hall of 'Abd al-Rahmān III (r. 300-350/912-961), ${ }^{6}$ now reconstructed using a large part of its original ornamentation (Figure 2) and showing the sumptuousness and importance of this protocol hall that was the scene of splendid receptions of the caliphs, which vied in splendour with those of Baghdad or Sāmarrā'. 


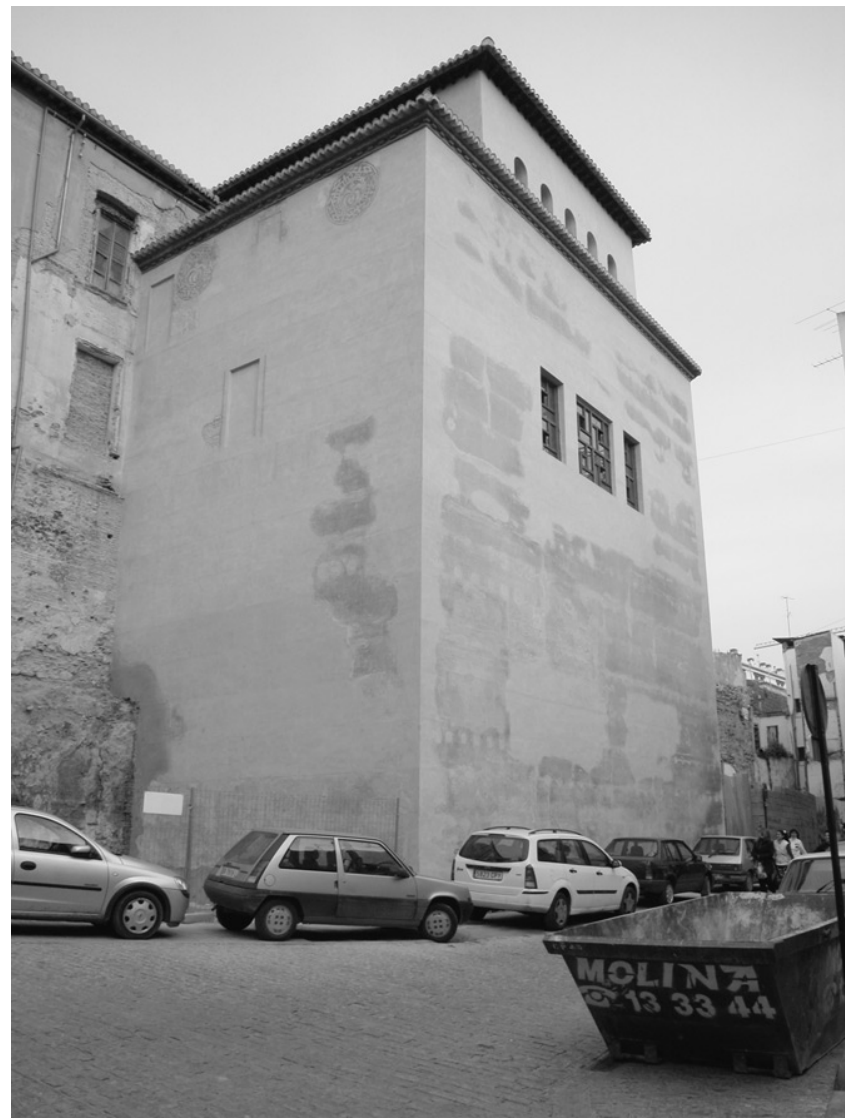

FIgURE 3. External view of the tower containing the qubba of the Cuarto Real de Santo Domingo in Granada.

The Cuarto Real of Santo Domingo in Granada ${ }^{7}$ differs completely from the previous case. Here we are dealing with a pavilion or qubba from the beginning of Nașrid times (about 1275) situated in a tower of the city wall (Figures 3 and 4) and which was undoubtedly used as a protocol hall, in the middle of a garden surrounded by orchards. This was preserved almost intact until the middle of the nineteenth century inside a convent, until it passed into private hands and underwent the disappearance of the portico and the transformation of the garden owing to the building of a dwelling inside the garden. The recent purchase of the monument by the Town Hall has allowed it to be restored, although there has been strong controversy over the final restoration.

The chamber is covered with a magnificent wooden ceiling (Figure 5), and for the preservation of this ceiling the roof has been completely renovated, using present-day techniques for construction with wood (Figure 6). During the process of cleaning the whitewash from the plasterwork, rich polychromatic decoration was discovered. The building also has a magnificent collection of glazed tiling or mosaics (zali $\bar{j}$ ) (Figures 4 and 7 ). The reason for the controversy lies in the claim by some technicians of the Civil Service to preserve the nineteenth-century building in

\footnotetext{
${ }^{7}$ Almagro and Orihuela (1997); Orihuela.
} 


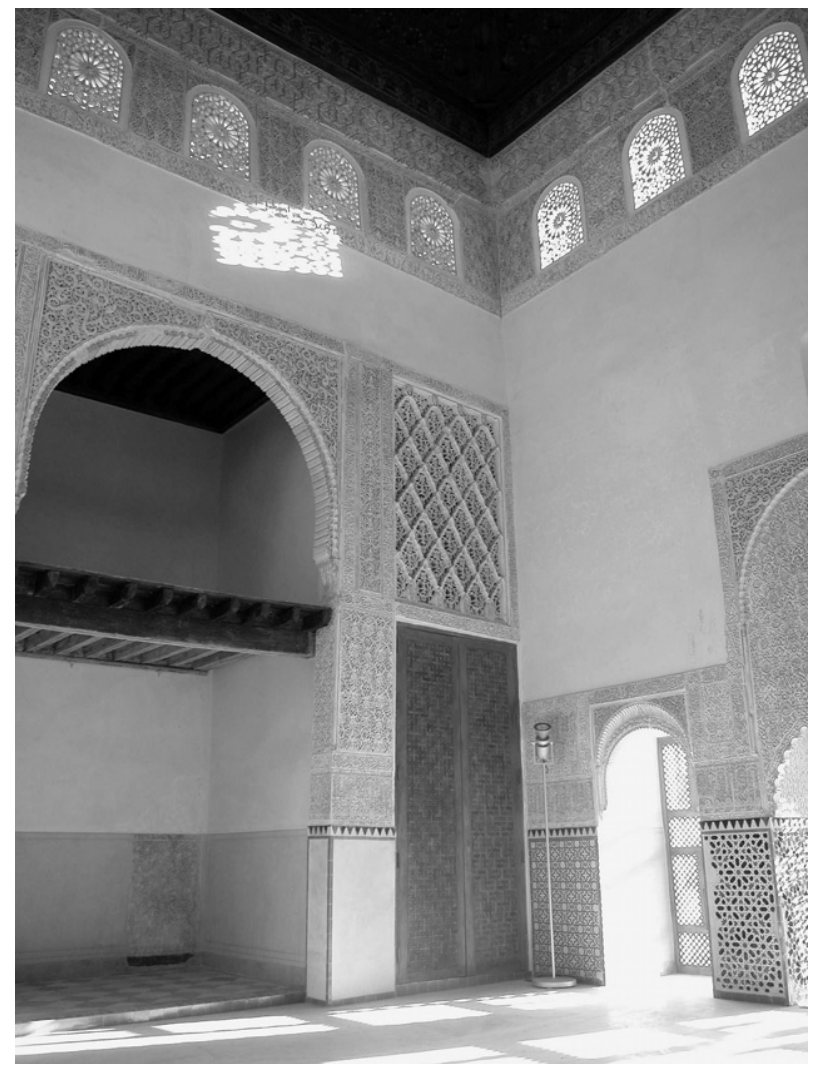

FIgURE 4. Interior view of the qubba of the Cuarto Real de Santo Domingo in Granada.

spite of its scant value and use, and which gave way to a proposal to convert it into a modern building with the addition of other even more questionable features such as an access ramp to the garden, built adjoining the original city wall. Our proposal meant the construction of a portico inspired by the original shape, of which there is some graphic evidence, but which can be easily recognised as a modern construction. The techniques of computer graphics facilitate the visualisation of this proposal (Figure 8). The elimination of the modern building would allow the structure of the original garden, at present buried, to be recovered, and above all a direct connection between chamber and garden would once more be restored, being the basic feature of the architectural concept behind the design of this building. ${ }^{8}$

In relation to this subject, it is also worth paying special attention to the work of preservation and recovery of the gardens, which were highly important features in Muslim culture and of which there were magnificent examples in al-Andalus, where they were a deeply-rooted tradition. To give just two examples, there is the recently finished work in the Patio de la Acequia in the Generalife, ${ }^{9}$ whose garden has been submitted to numerous transformations, of which we have abundant pictorial

\footnotetext{
${ }^{8}$ Almagro and Orihuela (1997).

${ }^{9}$ Bermudez; Casares et al., I and II.
} 


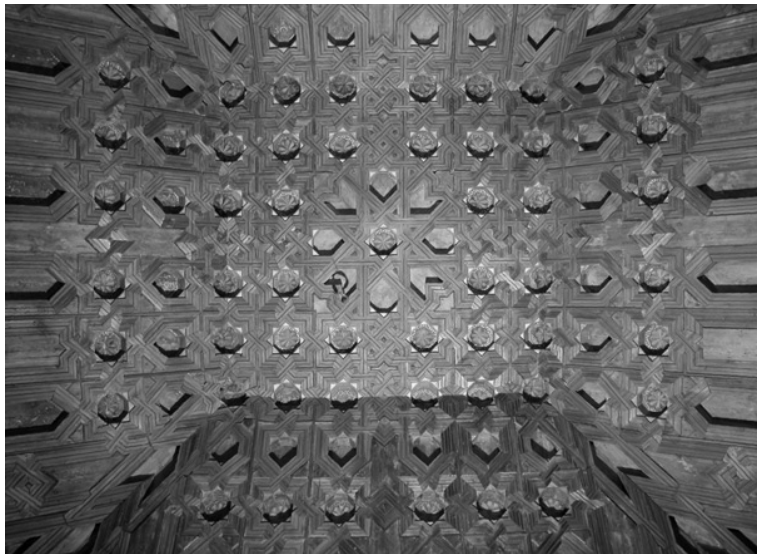

FIGURE 5. The wooden ceiling covering the qubba of the Cuarto Real de Santo Domingo in Granada.

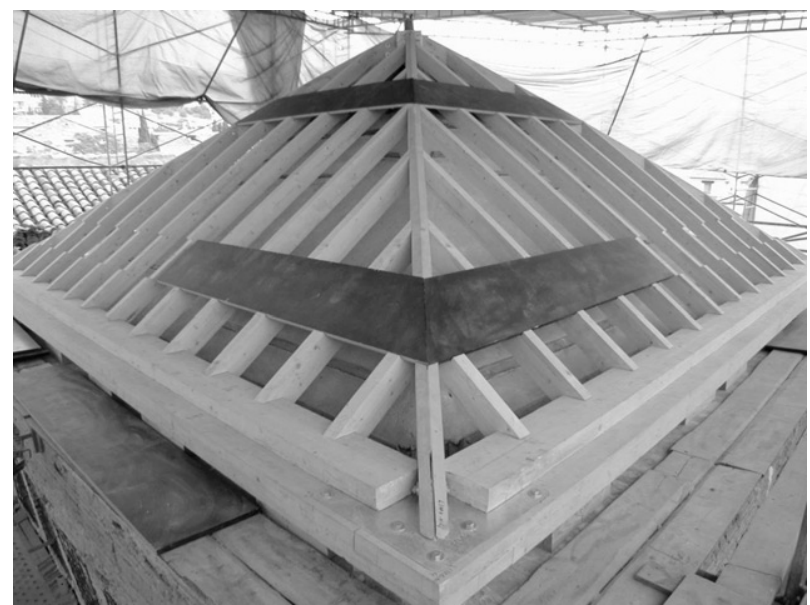

Figure 6. The new wooden structure of the roof of the Cuarto Real de Santo Domingo in Granada.

references, at least since photography has existed. A recent study into the documentary, archaeological, edaphic and botanical sources has led to the reorganization of the planting, substituting the previous motley vegetation and huge trees which concealed the view of the architecture (Figure 9), for plants of a smaller size like a carpet of flowers, probably in closer resemblance to the original form of the garden (Figure 10).

The discovery in 2002, in the Patio de las Doncellas in the Alcázar of Seville, ${ }^{10}$ of the structure of the original garden created for the unique palace of King Pedro I of Castile (r. 1334-1369), has led to the recovery of this garden that has recently been completed (Figure 11); this gives us an approximate idea of the shape of the site which was contemporary to the most outstanding Alhambra buildings.

10 Tabales. 


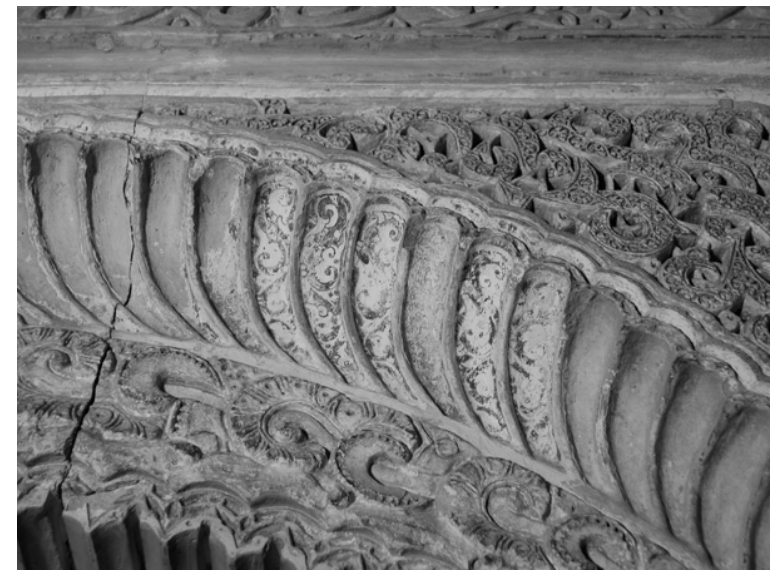

FIGURE 7. Detail of the painted decoration appearing under the white-wash that covered it.

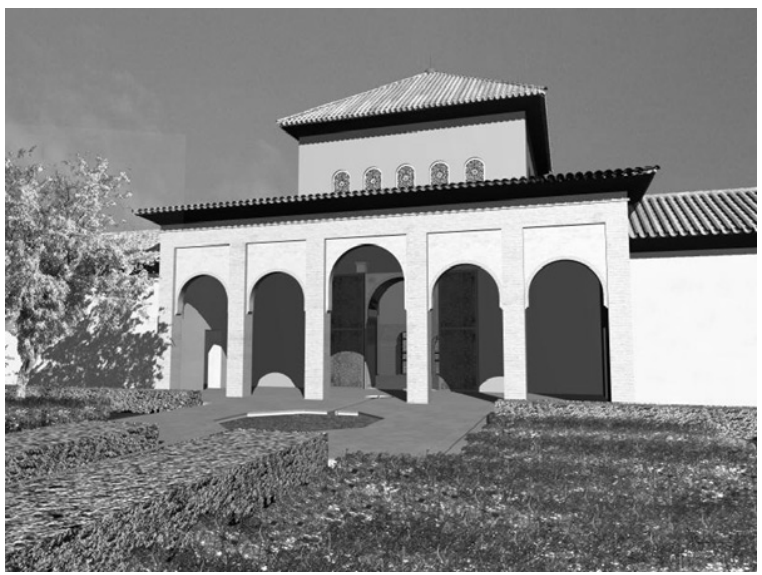

FIgURE 8. Proposal for the recovery of the (destroyed) ruins of the portico of the Cuarto Real de Santo Domingo.

The garden had two sunken flower beds surrounded by walls with decorative blind arches and a longitudinal pool used for both irrigation and the reproduction of fish. This structure disappeared later with the change in concept and use of the palace, when the garden was converted into a paved courtyard (Figure 12).

\section{A new concept of the conservation of cultural heritage}

Due to the restrictions set by present-day international criteria regarding reconstruction, most architectural work must necessarily be of a conservative nature with due respect to historical values, therefore often hindering the recovery of the image and perception of the original space in cases where there has been serious destruction or change. However, there are now other possibilities thanks to 


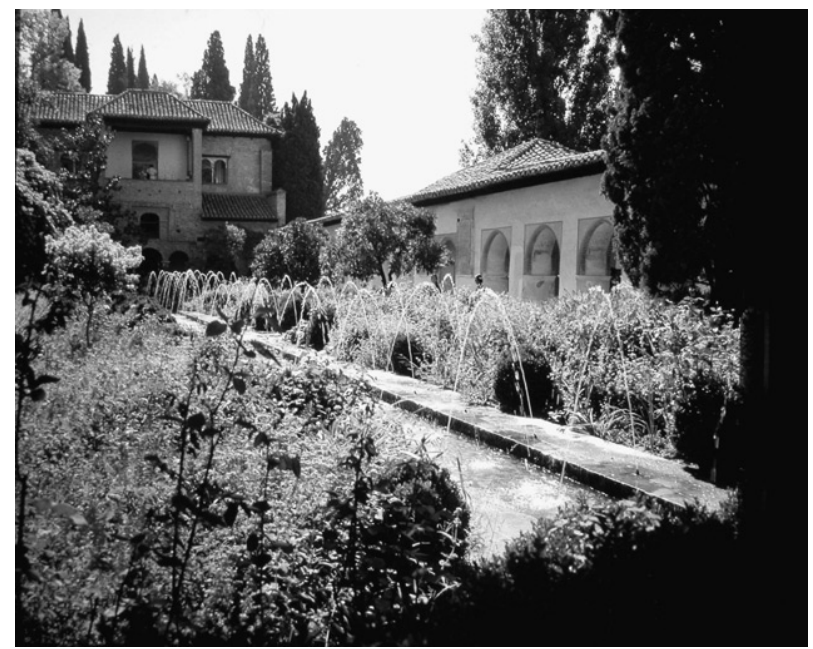

Figure 9. The Patio de la Acequia of the Generalife before the last restoration.

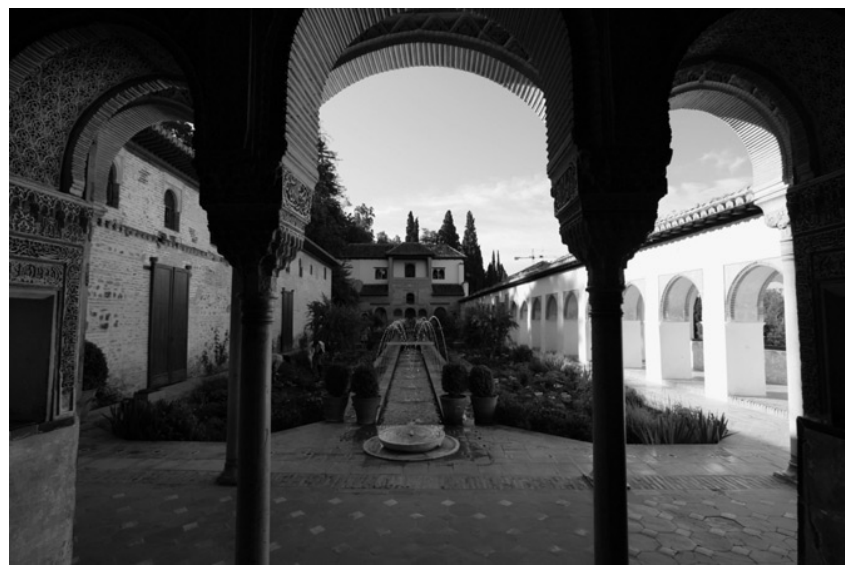

FIgure 10. The new aspect of the Patio de la Acequia of the Generalife after the restoration of the garden.

computing science, both for research into cultural heritage and for giving information on this patrimony to the general public.

Architecture taken as space adjusted to man's life can only be understood as a whole through sensory perception. Our capacity of imagination can to a certain extent add to that perception, although it may be difficult for those people who are lacking in experience or sufficient talent in this respect.

The virtual reconstruction of devastated or drastically changed buildings that is carried out by means of computer applications enables us to analyse such fundamental aspects as their visual perception, the importance to the space of aspects such as the colour and texture of the materials, the effects of light and even the scale of the building. With the use of these means, it is easy to present and study different alternatives or hypotheses without physically affecting the original buildings. 


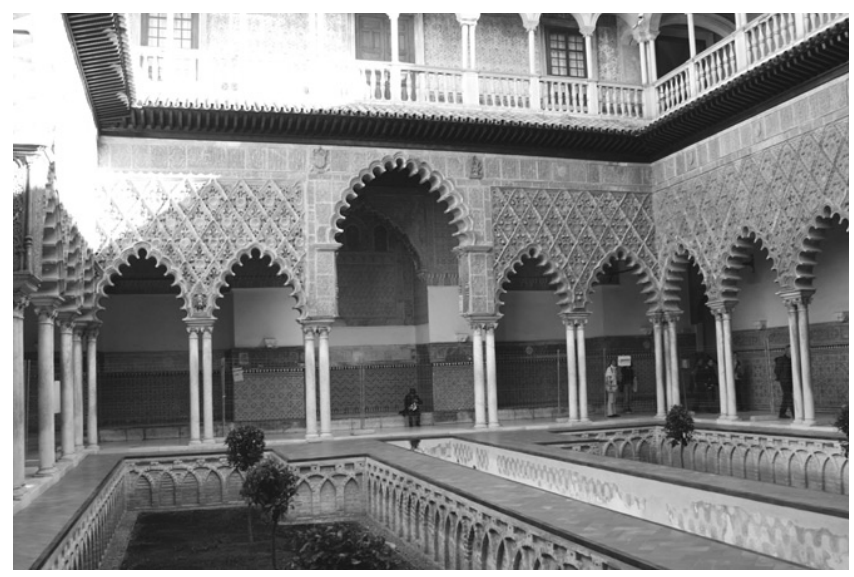

Figure 11. The Patio de las Doncellas in the Alcázar of Seville with its original recovered garden structure.

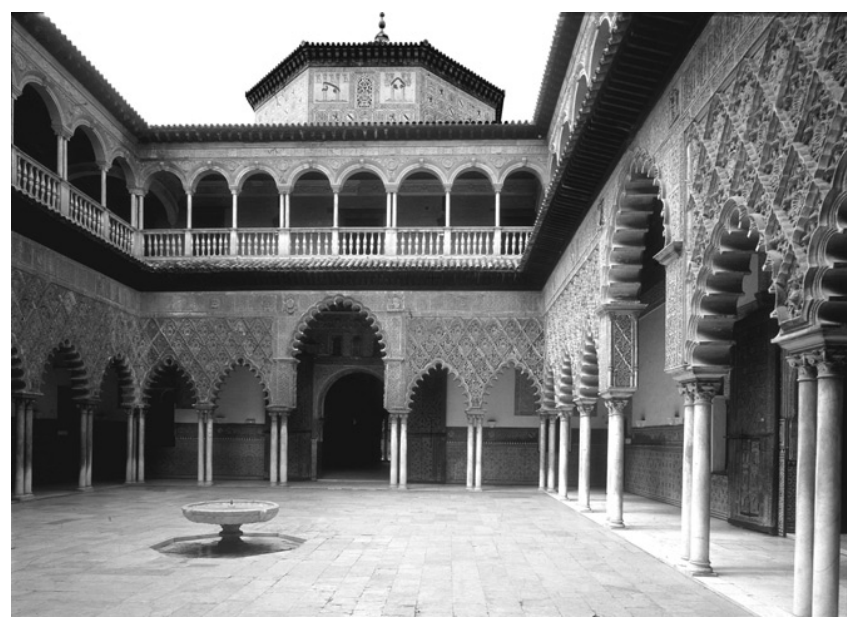

Figure 12. The Patio de las Doncellas before the last intervention.

Over recent years, computer science has provided us with new, powerful instruments for visualisation and representation that are revolutionary in the field of research of cultural heritage, as well as in other fields. At the end of the 1980s, the CAD systems already allowed for work with authentic three-dimensional representations, although for a considerable time only objects consisting of lines or "wires" were dealt with. The first versions which enabled us to work with plans and later with solids and allowed the possibility of "illuminating" these objects, even though in a rudimentary way, meant an important step forward. Nowadays, the capacity offered by rendering software, which allows for the incorporation of textures, any type of lighting and even the effects of "radiosity", makes them powerful tools which would have been unthinkable a few years ago, and which offer us access to a new system of "representation".

The possibilities opened up by new software or computer graphics are enormous. The visualisation of perspective views from any angle or condition, 
the re-creation of different states or solutions, whether of volumetric forms such as textures, colours or lighting, movies or panoramic views, offers the opportunity of constructing interactive systems for the user to participate in the choice of the different solutions/answers. The capacity to re-create objects, particularly architectural ones, which have been subjected to vast transformation or even ruin or disappearance, is one of the most interesting applications provided by the computer graphic systems. Since the analysis of material culture is the aim of archaeological studies, and the fact that architecture is one of the most important and vital expressions of this culture, the possibility of visually re-creating these remains when they have undergone significant changes that are sometimes difficult to imagine, is a potential aid to our work. ${ }^{11}$

All of these tools have multiple applications which enter into two general groups. One would facilitate reflection and research into the lost architectural heritage. Virtual reconstruction means that we must think about the elements as a whole, bear in mind solutions for all its details and components, and in the light of the images consider our final hypotheses and our work. Our experience in this respect has been very interesting. Since some years ago, ${ }^{12}$ we members of the research group on Islamic Architecture in the School of Arabic Studies have been resorting to these methods, in an attempt to give shape to our deductions and to revise the results as a way of examining the research in depth. On various occasions this procedure has made us reconsider our suppositions or take up questions which had not arisen before. In some cases this has enabled us to visualise different solutions and discuss them, not only as a hypothesis on the original state, but as proposals for restoration. In this sense, these systems avoid errors which can prove difficult or at least costly to correct, as they in no way affect the building or object and can therefore be considered as an absolutely "reversible" method.

Another useful application of these systems is the transmission of information. The traditional methods of representation, by means of ground plans, elevations and sections have always proved to be rather unintelligible for those who have neither knowledge nor experience of the systems of representation. Perspectives, much easier to understand, were previously laborious to carry out and therefore they were done in a more restricted way, due to the high costs. It was not always possible to get the most suitable points of view, but for the reason previously referred to they were rarely checked. This meant that the results of the research were not accessible to the general public, and therefore one of the main objectives of the investigation was not achieved, i.e., keeping society informed of the oncoming advances in knowledge. There is no doubt that this is one of the most interesting fields, as well as being one of the most useful ones to society, to the extent that probably in the near future it will be practically essential to use these tools to inform on the results of our research.

However, it is worth investigating and making a specific reflection on the development of the application of these systems. There are tools available that have been almost unknown up until now, and while their correct usage may produce magnificent results, their unsuitable use may give place to inadequate results and at the same time to negative reactions. In this respect, it should be taken into account

${ }^{11}$ Fernández.

12 Our first work was related with the Citadel of Amman (Jordan). See Almagro et al., "El palacio omeya", that includes a CD-Rom with the virtual reconstruction of the Umayyad citadel. 
that the use of these computer applications has spread widely between technicians and professional people who are quite unaware of our studies who, faced by the social demand for this type of representation, logically feel tempted to provide images that are often lacking in adequate scientific support. The problem may be both regarding the general concept of the hypotheses and the attempt to solve questions of detail, such as textures, materials or colours, or in the search of "photorealistic" views of which there is no evidence and that may give false ideas of the proposals.

Hence there should be two considerations: the first is that we cannot turn our back on these work methods with the excuse that they are a source of falsehoods. It will be the responsibility of those of us who work in the field of archaeological and architectural research to apply the required rigour to the proposals. If we do not do this on a scientific level, no doubt others lacking an adequate base will do so, and in any case, these types of representations will reach society, because society is demanding them. The second consideration is related to the final form and the detail we should give in our reconstructions and representations. Given the growing possibilities that computer applications allow us with regard to resemblance to reality on the subject of lighting, quality of the materials, etc., the level of realism that we can or should achieve must be decided on. Obviously the first question that arises is the quantity and quality of information available, and as a consequence the levels of uncertainty with which we have to work. Other than in exceptional cases, we will generally have limited information, since there is inevitably a loss of data in all cases of ruin and transformation. As a result of this we shall have to rely on parallel cases and complementary information in order to build up our hypotheses, which in many events will be just that, mere hypotheses with a greater or lesser degree of certainty.

\section{Criteria for virtual reconstruction}

In the process of restoration, there are criteria which are commonly accepted regarding the permissible extent of the intervention, and these criteria bear relation to the recognition of the authenticity of the object. It should always be possible to make a clear distinction between what is original and what is not, and between what is plausible and what is merely hypothesis, leaving this type of limited additions to the cases where it is necessary for reasons of conservation or stability of the building. In the case of virtual reconstruction these criteria obviously do not have to be so strict, as they have no direct effect on the building. Nevertheless, this should not be a reason for complete permissiveness. Although virtual reconstruction is an intellectual process, and therefore cannot be limited in any way, least of all legally, as are the interventions in cultural heritage, certain ethics should certainly be decided on, the same as should be valid for any scientific work. However, it is not easy to establish clear-cut limits regarding our capacity for "invention" when we are re-creating heritage which has been altered, destroyed and in many cases has disappeared. How far can we go in our hypotheses? It is certainly not easy to give a unanimous answer to this question, which must vary according to each case. Probably, rather than setting limits to the implications of our hypotheses, we should stress their explanation and justification, at the same time accepting the risk of 
incorrect usage that may be made of the images created, out of the context of the corresponding explanations.

Anyway, the treatment of the finishes of lighting and texture should be used as a means of expressing the reliability or certainty of the proposals. Normally the surfaces of buildings are the parts which suffer most, so in many cases it is hard to know their original colour or type of decoration. At any rate, it must not be forgotten that these surfaces define the nature of the architecture in a special way. Many of the great monuments as we see them nowadays have little in common with the aspect they offered to their original users, having lost both their colour and texture, which were some of the characteristic qualities of that image. Whenever there are data for the reconstruction of that aspect of the image, of course it is important to reveal it, but if this information is lacking, we must be cautious and restrict ourselves to a mere representation of the spaces and volumes using neutral textures and colours which may insinuate possible solutions, but not a realistic character which might be erroneous.

\section{Methodology}

It is also important to follow a work plan in this process, and one with a pattern guaranteeing suitable rigour. In the research group in the School of Arabic Studies we have been investigating this with certain experience behind us. The whole process always begins with a detailed survey, with measurement of the structures and their representation in floor plans, front elevation and sections. In order to do this, all the available systems are used, from direct measurement to topographic and photogrammetrical systems. Representation is carried out in AutoCAD, and if possible from the outset producing a three-dimensional model of the present state, thus facilitating the creation of the hypothetical model under reconstruction. The model of the present state should be as detailed as possible, including the actual shape of the structures, their deformation and damage and any information that might be of interest for a thorough study of the remains. These models, normally produced with photogrammetry, are only "wired", without surfaces or solid forms which are not possible in highly detailed drawings. The formulation of hypotheses begins by using these representations; as is to be expected, AutoCAD is always used, and all the available elements are analysed, as are the parallels that are equally well documented in AutoCAD drawings, in the planimetrical database of architecture of al-Andalus which has been produced over the last fifteen years.

Once the hypotheses have been stated, in a process which we, the investigators specialised in Islamic architecture carry out, other specialists in computer graphics subjects continue the work, under the coordination of Professor José Antonio Fernández Ruiz (who forms part of the research group) of the Granada School of Architecture. As from this moment, the creation of a virtual model begins, taking as a starting point the model of the hypothesis. This process generally requires the model to be simplified in an attempt to reduce it to simple geometric forms, in the search for the theoretical geometric form of the elements that will facilitate the formation of surfaces and solids. Construction of the scale model also requires following a process of analysis and decomposition of objects that generates a variety of elements used repetitively, in order to reduce in size the memory of the virtual scale model as much as possible. This simplification should also entail the 


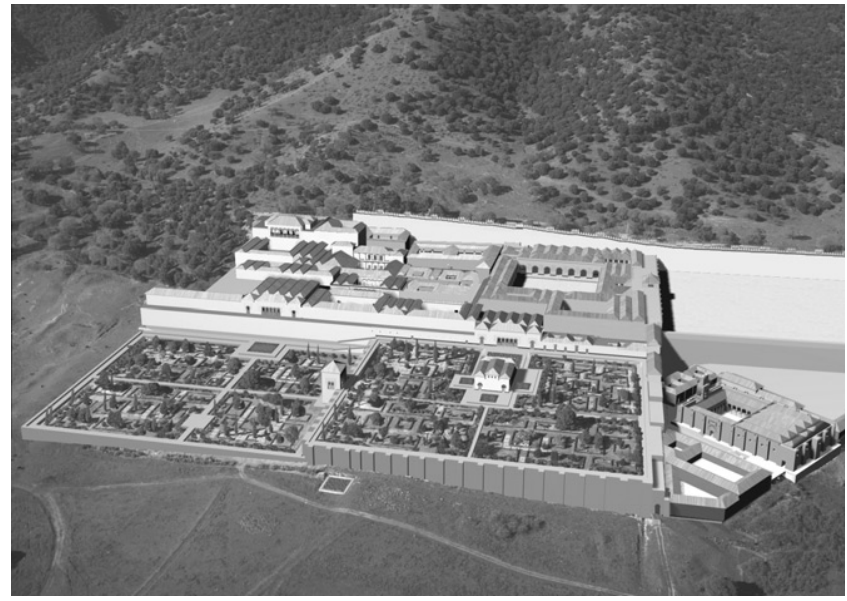

FIGURE 13. Virtual reconstruction of the Alcázar of Madīnat al-Zahrā' (hypothesis by the author, image by $M$. González).

determination of symmetry, rotation or matrix which simplifies the construction of the model.

Once the scale model has been set up in AutoCAD, it is exported to 3Dstudio Viz software where materials with textures, colours and lighting are incorporated. This software offers various possibilities: visualising different views, changing the lighting and, finally, obtaining different images which are considered to be of interest. They can be modified or re-created at any time and, by obtaining series of images from points along a dotted line, animation can be achieved, thus accentuating the three-dimensional perception and enabling a fuller understanding of the space.

\section{Examples of virtual reconstruction}

As an example of some of the reconstruction work we have done up until now, we can provide different images of significant buildings in al-Andalus, including some of those which have been dealt with previously and whose problems we have analysed.

A particularly unique case is that of Madinnat al-Zahrā', where there has been the reconstruction of the treatment and interior surfaces according to the remains which appeared in sundry areas of the site. The architecture of Madinnat al-Zahrā' offers facilities planning its reconstruction thanks to its "classical" and canonical nature, since it follows models and patterns of composition which can be easily deduced. Thanks to the anastylosis of the elements which it has been possible to rebuild, particularly the decorative panels, we have at our disposal a quantity of information related to the elevation of many of the buildings. ${ }^{13}$ This has aided us in formulating hypotheses on which to carry out a visual reconstruction of the whole site (Figure 13). In spite of having undergone changes throughout the period of its construction and its short-lived existence, the fact that this palatine city was

${ }^{13}$ Almagro et al., "Madinat al-Zahra". 


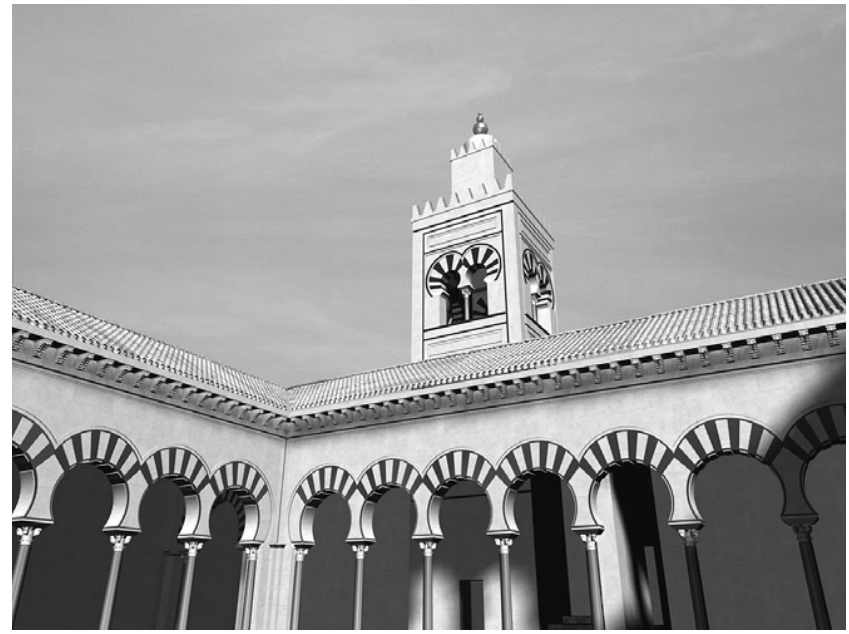

FIgURE 14. Virtual reconstruction of the courtyard and minaret of the mosque of Madinat al-Zahrā' (hypothesis by the author, image by M. González).

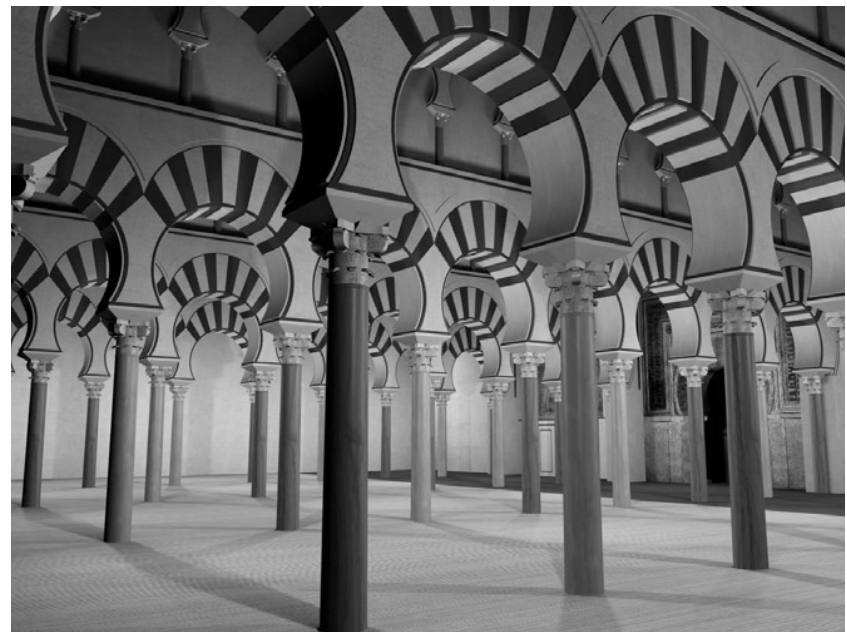

FIGURE 15. Virtual reconstruction of the prayer room of the mosque of Madinat al-Zahrā' (hypothesis by the author, image by M. González).

destroyed at a very early date without the possibility of a continuous transformation over the ages, makes the definition of its original form much easier.

We know the ground plans of the mosque of Madinat al-Zahrā' from the traces of the walls, which in many cases have not even the slightest of foundations. We also have in situ some of the columns as well as many decorative elements. There are even descriptions providing data about the height of its minaret. With this information we have been able to propose a complete reconstruction of the whole building, of which an illustration is provided (Figures 14 and 15).

The gardens are particularly significant in this site, as they are set out in great terraces within domestic courtyards. The virtual images improve our perception of 


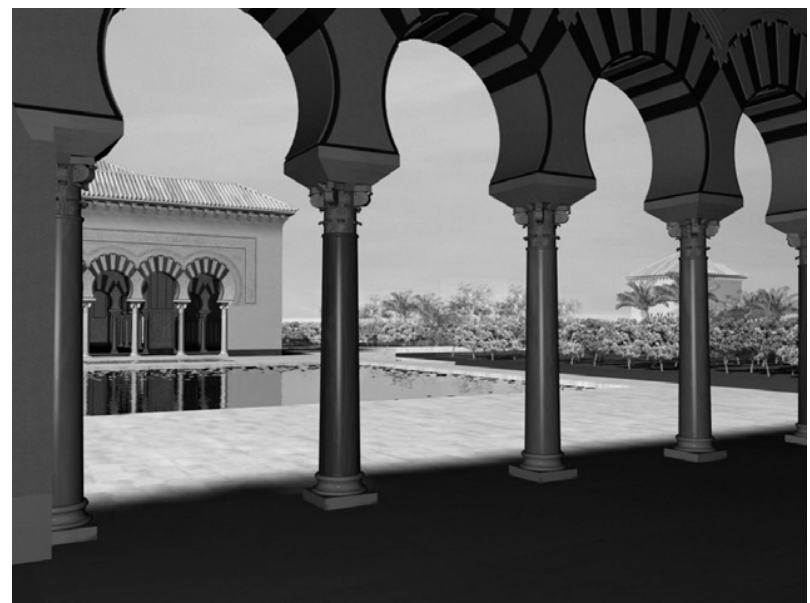

FIgURE 16. The central pavilion and the gardens of the "upper terrace" view from the portico of the reception hall of 'Abd al-Rahmān III in Madinat al-Zahrā' in a virtual reconstruction (hypothesis by the author, image by M. González).

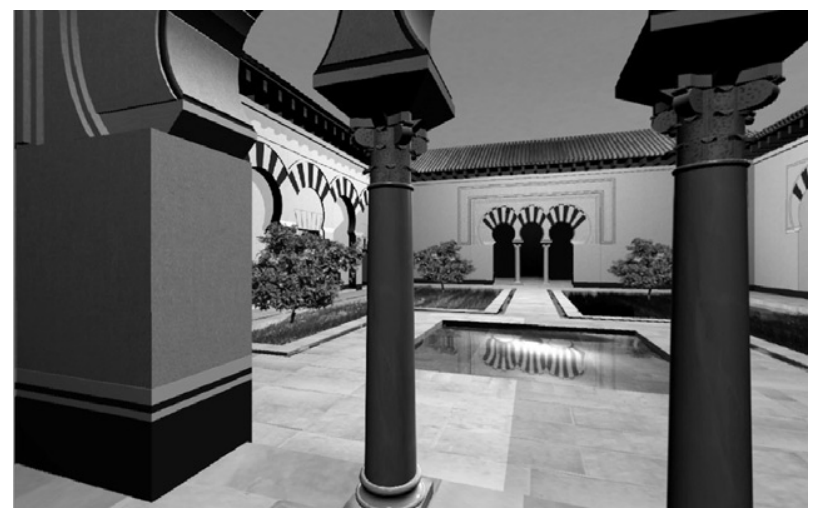

Figure 17. Virtual reconstruction of the Patio de la Alberquilla in Madinat al-Zahrā' (hypothesis by the author, image by M. González).

these areas and allow us to imagine their inter-relationship with the architecture. The effects of light and shade are also re-created, together with the function of luminous diaphragms performed by the successive arches in perspective. All of this enables us to experience some of the qualities of this architecture to a high degree of realism. Some of the most outstanding areas that should be mentioned are the great reception hall of 'Abd al-Raḥmān III, with its pavilion opposite located in the middle of the gardens of the Upper Terrace, surrounded by pools, water channels and vegetation (Figure 16). The "house of the Alberquilla" shows us a secluded and domestic area in harmony with the use of this building, which must have been the main accommodation of some prince or dignitary of the caliph's court. The two facing porticos led the way into the two main halls, and they formed the back of a quiet garden which we can imagine full of flowers and some ornamental or fruit trees (Figure 17). In front of the western portico there is a small pool with a descending stairway, and we can imagine that mitigated the heat as well as being 
used for watering the plants. For this purpose there are small stone channels bordering the flower beds.

One really useful application of these visual instruments is the one which shows the changes that have taken place over the years to areas or buildings which have undergone considerable transformation in the taste or culture of their inhabitants. The substantial changes undergone by the Courtyard of the Crucero in the Alcazar of Seville ${ }^{14}$ make it an interesting case. This building was undoubtedly the main residence of the palace at the end of the twelfth century, in Almohade times. As well as being one of the largest residential buildings in al-Andalus, it must also have been one of the most original ones. Together with the characteristic layout of Andalusian houses, with two large halls facing each other and preceded by their corresponding porticos, it has the unique feature of a large garden in the patio, sunken more than four metres with respect to the level of the halls. This arrangement enables the uniting in one single area of the functions of garden and courtyard, and while from the rooms there is an open ambiance with carpet-like green, from the lower level of the garden and pools to the foliage, we can imagine, the buildings would have remained concealed from the eyes of the passers-by. This building was subjected to a very considerable transformation when it became converted into the royal residence of the Christian monarchs. The general layout of the courtyard, characteristic of any Muslim palace, was preserved, while one of its sides was reconstructed in Gothic style in the second half of the thirteenth century. Several rooms with Gothic vaulting replaced the original hall to accommodate a more numerous and formal court. To access these areas a raised passage was built over the garden, supported by vaulted porticoes dividing it in four parts, to form a cross. This layout underwent a drastic change when the gardens were buried in the eighteenth century and the façades of the courtyard were transformed in the Baroque style, with the result that these days it is difficult to understand the different stages this unique building passed through. The possibility of using virtual reconstruction in each of these situations not only facilitates our understanding of the history and characteristics of this architectural work, but it also gives the investigator a better insight into his work.

The images reproduced here show the state of the courtyard at two different historical moments, one in Islamic times (Figure 18) and the other following the changes in the time of Alfonso $\mathrm{X}$ the Wise (r. 1221-1284) (Figure 19). Both situations are difficult to comprehend nowadays in the view of the present circumstances. The images we have taken form part of an audiovisual montage carried out to allow visitors a better comprehension of the monument. ${ }^{15}$

Another interesting case is the Almohad mosque of Seville. It was one of the largest religious buildings in Western Islam, and once converted into a church, it existed until the fifteenth century, with the beginning of the construction of the new cathedral on the same site, which became the largest Gothic cathedral in Europe. The remains in the courtyard and those from the excavations underneath the cathedral, ${ }^{16}$ as well as the canonical and regular features of its architecture, provide us with a reliable idea of its original shape and structure. With this information and that from other contemporary buildings, it has been possible to produce a very

\footnotetext{
${ }_{14}$ Almagro (1999).

${ }^{15}$ Almagro and Almagro; Almagro (2005).

${ }^{16}$ Jiménez.
} 


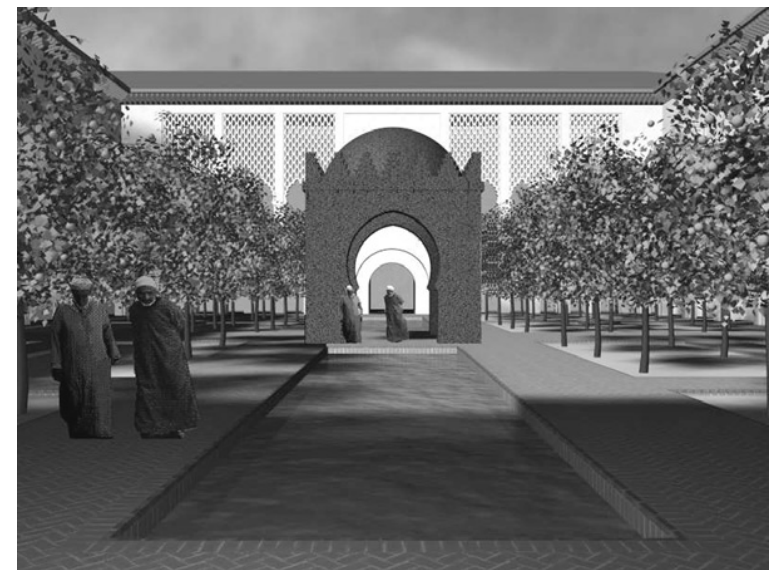

FIgURE 18. Virtual reconstruction of the Patio del Crucero in the Alcázar of Seville with its original Islamic structure (hypothesis by the author, image by Ana Almagro and M. González).

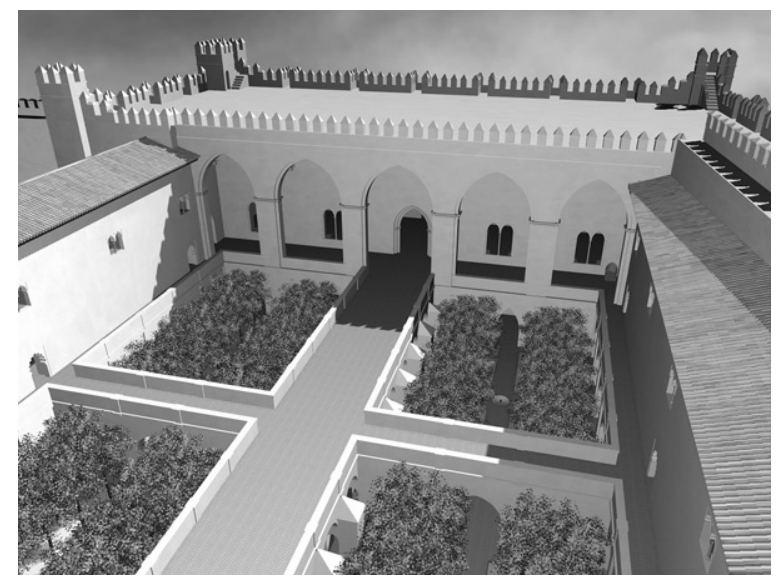

Figure 19. The Patio del Crucero after its transformation in the thirteenth century in a virtual reconstruction (hypothesis by the author, image by M. González).

credible image of the original shape and structure of this great historical monument whose size and subtle elegance are impressive when we look at it in these images (Figures 20-21).

Other cases of interest in Granada are the Cuarto Real of Santo Domingo and the Maristan. We have already had occasion to mention the former at the beginning of this article, when we gave the proposal for its restoration. In the images presented we can appreciate a hypothesis of how this garden pavilion might have been according to the archaeology and graphic documents of the nineteenth century (Figure 22) ${ }^{17}$ The view from the interior is particularly relevant, offering the possibility to contemplate the garden through the entry arch and portico, something which is essential to understand the meaning of this type of building (Figure 23).

${ }^{17}$ Compare this hypothesis with our proposal for restoration in Figure 8. 


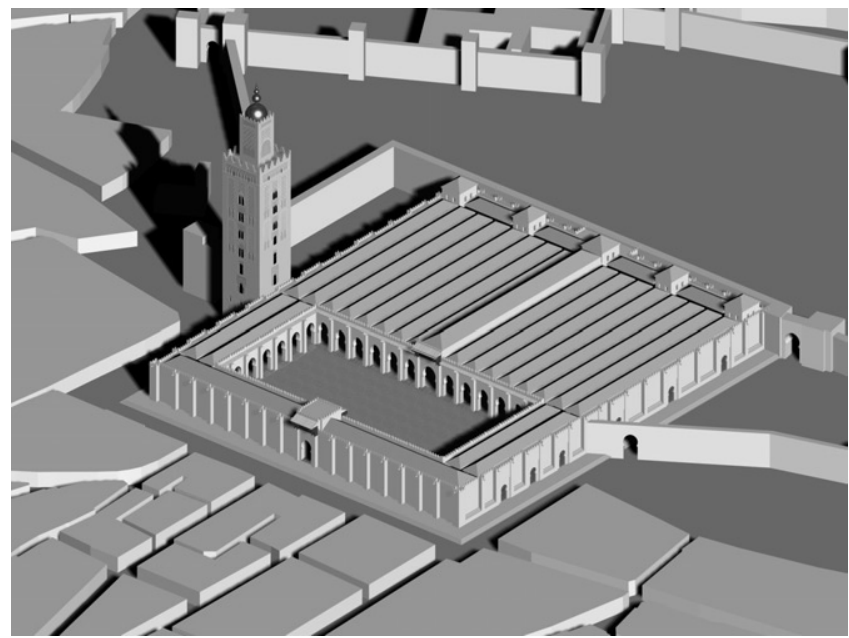

FIgURE 20. Aerial view of the Almohad mosque of Seville in a virtual reconstruction (hypothesis by the author, image by J. A. Fernández and M. González).

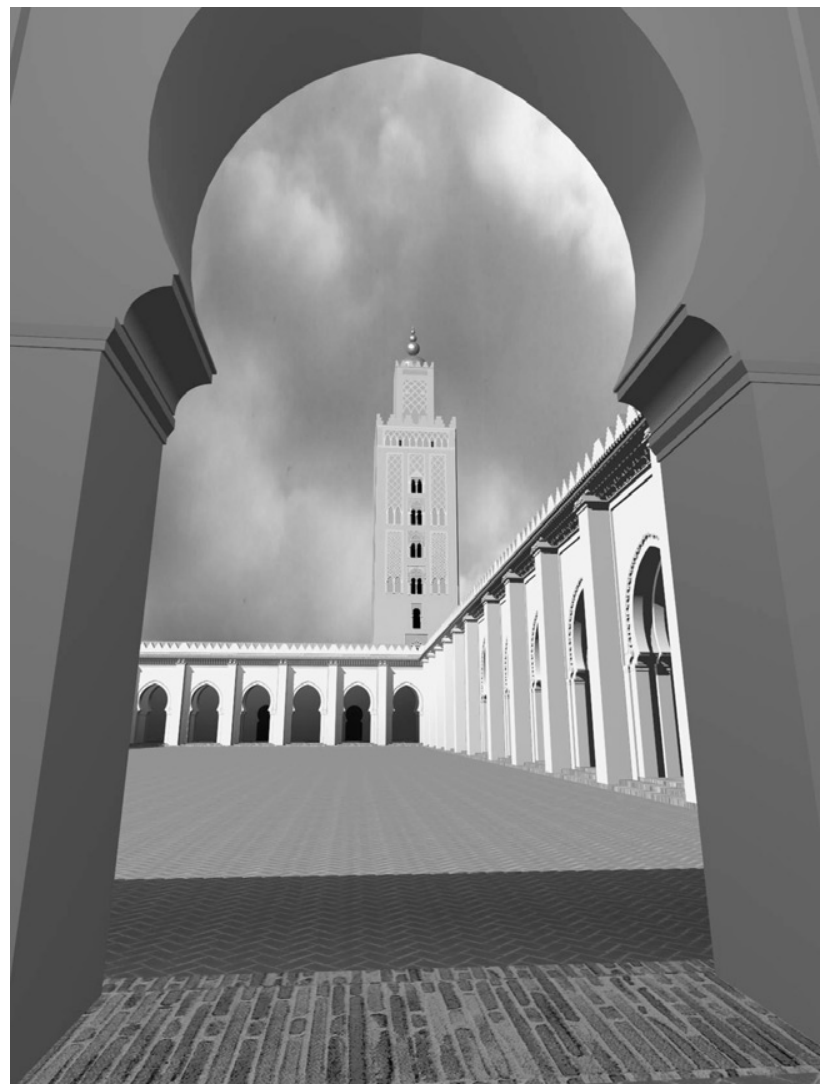

Figure 21. Virtual reconstruction of the courtyard of the Almohad mosque of Seville with the minaret, the actual tower of la Giralda (hypothesis by the author, image by J. A. Fernández and M. González). 


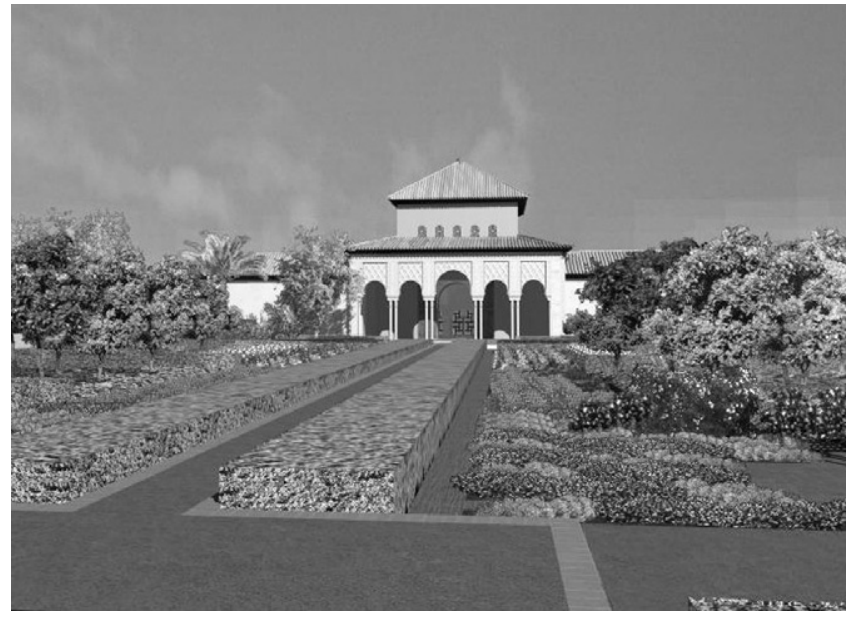

Figure 22. The qubba of the Cuarto Real de Santo Domingo and the gardens, in a virtual reconstruction (hypothesis by the author and A. Orihuela, image by M. Gozález).

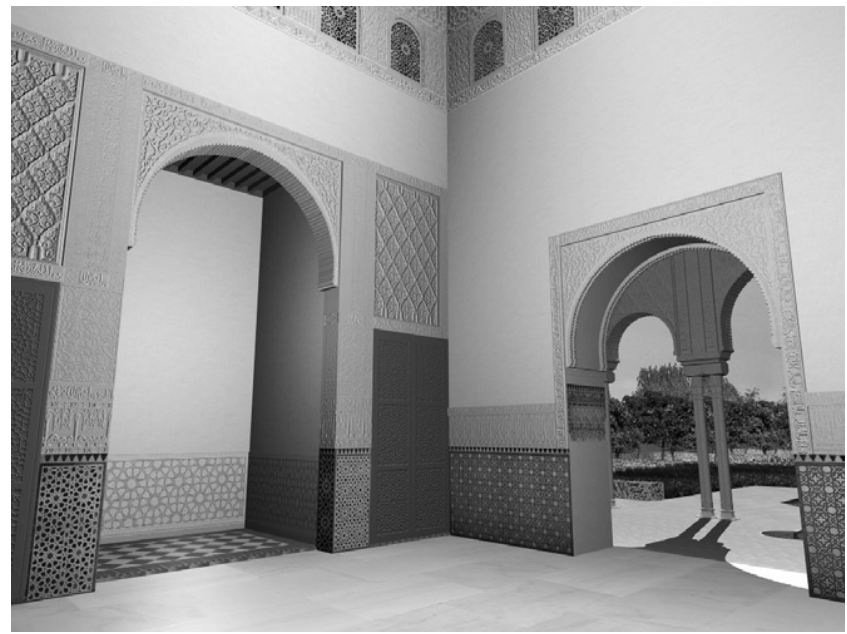

FIgURE 23. Virtual reconstruction of the interior of the qubba of the Cuarto Real de Santo Domingo (hypothesis by the author and A. Orihuela, image by M. Gozález).

The ancient Maristan of Granada, which was a hospital founded in $769 / 1367$ by Mohammed V (second reign 763-793/1362-1391), has had a sad history in the city of Granada. ${ }^{18}$ It is the only building of this type in al-Andalus of which we have exact information, and of which there are sufficent remains to analyse its layout and structure. The civil typology of the Maristan responds to a model deeply rooted in Islamic architecture. It is a building with a central courtyard with porticos and bays of rooms around it, inward-looking, and with the entrance door as the sole communication with the outside (Figure 24). The absolute rationality of the

\footnotetext{
${ }^{18}$ Almagro and Orihuela (2003).
} 


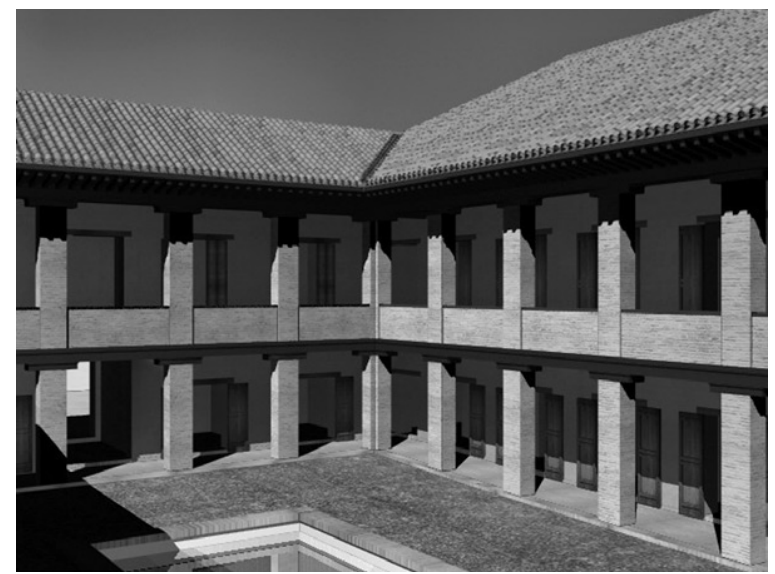

FIGURE 24. Virtual reconstruction of the courtyard of the Maristan in Granada (hypothesis by the author and A. Orihuela, image by L. Gómez).

original building gives it a certain air of modernity. Both the simplicity and funcional nature of its shape and also its spatial and typological layout enable us to ascertain its original layout, thanks to the remains which are still standing.

\section{Conclusion}

The conservation of historical heritage, particularly the architectural heritage, should start from the assumption of an adequate knowledge of the subject, since this can be considered to form part of that heritage. How to understand and evaluate a building at any given moment is an integral part of its history. The study of architecture must necessarily be based on the use of graphic instruments, both for its analysis and for its spreading. Only an adequate knowledge of something will fully guarantee its conservation. Hence the importance of doing research in depth and applying new methods which allow us to include aspects which were previously not analysed, such as the perception of spaces, the use of light and colour, etc., which can hardly be analysed in a ruin or building which has been drastically transformed. We believe that the examples set out illustrate fairly explicitly the possibilities offered by computer graphics in the field of archaeological research and the spreading of knowledge. At the same time they demonstrate the possibility of solving questions not previously brought up, or which could not be solved using traditional means, both in the field of investigation and in restoration. We have no doubt that in the future this type of work will be the object of generalised dedication and development that will allow a wider knowledge of architecture of the past, and a wider discussion among researchers of the proposed hypotheses.

\section{Bibliography}

Almagro, Antonio, "Jardín con plantas (y alzados) de papel”, in Arquitectura en al-Andalus. Documentos para el siglo XXI, ed. A. Jiménez (Barcelona, 1996), pp. 205-284.

----, "El Patio del Crucero de los Reales Alcázares de Sevilla”, Al-Qantara, 20 (1999): 331-376. 
----, "La arquitectura en al-Andalus en torno al año 1000. Medina Azahra", in La Península Ibérica en torno al año 1000. VII Congreso de Estudios Medievales (León, 2001), pp. 165-191.

---- (dir.), The Crucero Courtyard in the Alcazar of Seville, CD-Rom (Granada, 2005).

Almagro, Antonio and Antonio Orihuela, "Propuesta de intervención en el Cuarto Real de Santo Domingo (Granada)", Logia, 4 (1997): 22-29.

Almagro, Antonio, Pedro Jiménez and Julio Navarro, El Palacio Omeya de Amman III. Investigación arqueológica y restauración 1989-1997 (Granada, 2000).

Almagro, Antonio and Ana Almagro, "La expresión gráfica en el análisis del Patrimonio: El patio del Crucero del Alcázar de Sevilla", in Actas del IX Congreso internacional de Expresión Gráfica Arquitectónica, EGA 2002, Re-Visiones: enfoques en docencia e investigación (La Coruña, 2002), pp. 517-522.

Almagro, Antonio and Antonio Orihuela, "El Maristán de Granada", Boletín de la Real Academia de Nuestra Señora de las Angustias de Granada, 10 (2003): 80-109.

Almagro Gorbea, Antonio, Ana Almagro Vidal, José A. Fernández Ruiz and Miguel González Garrido, "Madinat al-Zahra, Investigación y Representación", in VIII Congreso Ibero-Americano de Gráfica Digital, SIGraDi 2004, El sentido y el universo digital (Sao Leopoldo, 2004), pp. 47-49.

Alvarez Lopera, José, "La Alhambra entre la conservación y la restauración (1905-1915)", Cuadernos de Arte de la Universidad de Granada, 29-31 (1977):1-240.

Bermúdez Pareja, Jesús, "El Generalife después del incendio de 1958”, Cuadernos de la Alhambra, 1 (1965): 9-39.

Casares, Manuel, José Tito and Esther Cruces, "El jardín del Patio de la Acequia del Generalife. I. Su evolución en la documentación escrita y gráfica", Cuadernos de la Alhambra, 39 (2003): 63-86.

Casares, Manuel, José Tito and Oswaldo Socorro, "El jardín del Patio de la Acequia del Generalife. II. Consideraciones a partir del análisis palinológico", Cuadernos de la Alhambra, 39 (2003): 87-108.

Chávez, M. Rosario, El Alcázar de Sevilla en el siglo XIX (Sevilla, 2004).

Fernández Ruiz, J. A., "El renacimiento del patrimonio a través del dibujo digital”, in Actas del Congreso Nacional: El Dibujo del fin del milenio (Granada: Facultad de Bellas Artes, 2000), pp. 247-250.

Hernández Giménez, Felix, Madinat al-Zahra', Arquitectura y decoración (Granada, 1985).

Jiménez, Alfonso, "Las mezquitas", in Sevilla Almohade, eds. M. Valor and A. Tahiri (Sevilla-Rabat, 1999), pp. 89-105.

Jiménez, Alfonso (ed.), Magna Hispalensis I (Sevilla, 2002).

Marín Fidalgo, Ana, El Alcázar de Sevilla bajo los Austrias (Sevilla, 1990).

Nieto Cumplido, Manuel, La Catedral de Córdoba (Córdoba, 1998).

Orihuela, Antonio, Casas y palacios nazaries. Siglos XIII-XV (Barcelona, 1995).

Tabales, Migule Ángel, "Investigaciones arqueológicas en el Patio de las Doncellas", Apuntes del Alcázar de Sevilla, 4 (2003): 6-25.

Vallejo, Antonio, "El salón de 'Abd al-Rahman III: Problemática de una restauración”, in El Salón de Abd al-Rahman III, ed. A. Vallejo (Córdoba, 1995), pp. 9-40.

Velázquez Bosco, Ricardo, Medina Azzahra y Alamirilla (Madrid, 1912).

Vilchez, Carlos, La Alhambra de Leopoldo Torres Balbás (obras de restauración y conservación 1923-1936) (Granada, 1988). 